\title{
PENINGKATAN KINERJA GURU MI DI KECAMATAN JUMO TEMANGGUNG DALAM PENILAIAN BERBASIS KELAS MELALUI SUPERVISI KLINIS
}

\author{
Nur Makhsun \\ nurmakhsun515900@gmail.com \\ Kementerian Agama Temanggung
}

DOI: $10.21580 /$ wa.v7i1.6506

\begin{abstract}
Abstrac
The purpose of this supervisory action research (PTKp) was to determine the performance improvement of MI teachers at Madrasah Ibtidaiyah in Jumo District, Temanggung Regency in carrying out class-based assessments through clinical supervision. In this supervisory action research (PTKp) was carried out in 3 cycles, from the results of the actions taken, it was proven to improve teacher performance by achieving ideal standards. to III $86.76 \%$. The results of this action research indicate that coaching through clinical supervision of supervisors can improve teacher performance in carrying out class-based assessments with completeness reaching $100 \%$.
\end{abstract}

Keywords: Teacher Performance, Class-Based Assessment, Clinical Supervision of Supervisors

\begin{abstract}
Abstrak
Tujuan penelitian tindakan kepengawasan (PTKp) ini adalah untuk mengetahui peningkatan kinerja guru MI di Madrasah Ibtidaiyah di Kecamatan Jumo, Kabupaten Temanggung dalam melaksanakan penilaian berbasis kelas melalui supervisi klinis. Dalam penelitian tindakan kepengawasan ( PTKp ) ini dilakukan dalam 3 siklus, dari hasil tindakan yang dilakukan terbukti dapat meningkatkan kinerja guru dengan mencapai standar ideal.Dari 64,41\% pada siklus I, dapat meningkat menjadi 76,17 \% pada siklus II, dan siklus ke III $86,76 \%$. Hasil penelitian tindakan ini menunjukkan bahwa pembinaan melalui supervisi klinis pengawas dapat meningkatkan kinerja guru dalam melaksanakan penilaian berbasis kelas dengan ketuntasan mencapai $100 \%$.
\end{abstract}

Kata Kunci : Kinerja Guru, Penilaian Berbasis Kelas, Supervisi Klinis Pengawas 
54 Peningkatan Kinerja Guru MI ....

\section{A. Pendahuluan}

Kualitas pendidikan sangat ditentukan oleh guru. Apalagi implementasi Peraturan Pemerintah No. 19 tahun 2005 tentang Sistem Pendidikan Nasional membawa implikasi terhadap model dan teknik penilaian yang dilaksanakan di kelas. Untuk menghasilkan tamatan yang mempunyai kemampuan utuh diharapkan pada kurikulum tingkat satuan pendidikan (KTSP) maupun kurikulum 2013, peserta didik menguasai kompetensi yang ditetapkan. Berkaitan dengan hal tersebut, diperlukan pengembangan pembelajaran / pelatihan kompetensi secara sistematis dan terpadu, agar peserta didik dapat menguasai setiap kompetensi secara tuntas.

Posisi guru sangat strategi untuk mewujudkan upaya pencapaian mutu pendidikan di Indonesia. Guru adalah ujung tombak yang sangat menentukan dalam sistem pendidikan secara keseluruhan, yang harus mendapatkan perhatian sentral, pertama, dan utama. Perbaikan kualitas pendidikan dapat dimulai dari guru. Maka peningkatakn kinerja guru wajib terus digelorakan dengan berbagai tindakan. ${ }^{1}$ Dalam rumus pendidikan, guru menjadi sopir dalam pendidikan. Meningkatkan mutu guru sama dengan meningkatakan mutu pendidikan. Kompetensi guru harus ditingkatkan tidak hanya pada wilayah administratif, namun harus menyasar pada kualitas, mutu, dan inovasi dalam pembelajaran di kelas. ${ }^{2}$ Peningkatan kinerja dan kompetensi guru merupakan amanat desentralisasi dan otonomi pendidikan. Sekolah/madrasah dapat melakukan pengembangan potensi masing-masing guru sesuai otonomi yang ada. ${ }^{3}$

Untuk mewujudkan hal itu dibutuhkan guru yang tidak sekadar guru. Artinya, selain memenuhi empat kompetensi pembelajaran, guru harus menguasai delapan keterampilan mengajar dan guru harus berjiwa revolusioner. Cirinya selalu update dengan isu-isu terkini, melakukan inovasi, menggali ide, dan mencari solusi dari problematika pembelajaran pembelajaran, baik dari aspek metode, model, pendekatan atau strategi pembelajaran. ${ }^{4}$

Kemampuan guru dalam mengajar dapat dilihat dari kinerjanya. Kemampuan dasar guru teridiri atas beberapa hal. Pertama, kemampuan merencanakan pembelajaran. Kedua, mengelola program belajar mengajar. Ketiga, mengelola kelas. Keempat, menggunakan media/sumber belajar. Kelima, mengelola interaksi belajar mengajar. Keenam, melaksanakan evaluasi belajar siswa. Sedangkan kinerja guru sangat terkait dengan efektifitas guru dalam melaksanakan fungsinya. ${ }^{5}$

Dalam hal ini peran pengawas sangatlah penting untuk mewujudkan kinerja guru melalui kegiatan supervisi klinis. Secara konseptual, supervisi klinis adalah sebuah pembinaan

\footnotetext{
${ }^{1}$ Lailatussaadah, "Upaya Peningkatan Kinerja Guru," INTELEKTUALITA 3, no. 1 (2015): 16.

${ }^{2}$ Hamidulloh Ibda, "Peningkatan Kompetensi Profesional Guru SD/MI Melalui Menulis Di Media," Tarbawi: Jurnal Pendidikan Islam 14, no. 1 (2017): 47, https://ejournal.unisnu.ac.id/JPIT/article/view/610.

${ }^{3}$ E Mulyasa, Menjadi Guru Profesional, Menciptakan Pembelajaran Kreatif Dan Menyenangkan (Bandung: Remadja Rosdakarya, 2009), 5.

${ }^{4}$ Hamidulloh Ibda; Dian Marta Wijayanti, Siapkah Saya Menjadi Guru SD Revolusioner? (Depok: Kalam Nusantara, 2014), 89.

${ }^{5}$ Muhardi, "Peningkatan Kinerja Guru Dalam Melaksanakan Pembelajaran Yang Efektif Melalui Supervisi Observasi Kelas Di SMK Negeri 1 Sambelia Tahun Pelajaran 2018/2019," Journal Ilmiah Rinjani_Universitas Gunung Rinjani 7, no. 2 (2019): 154.
} 
performansi guru dalam mengelola proses pembelajaran di kelas. Pelaksanaannya dirumuskan dengan praktis dan rasional. Desain maupun pelaksanaannya dilakukan atas dasar analisis data mengenai kegiatan-kegiatan di kelas. Data dan hubungan antara guru dengan supervisor merupakan dasar program prosedur dan strategi pembinaaan perilaku mengajar guru dalam mengembangkan belajar peserta didik. Aspek supervisi klinis ditekankan pada lima hal, yaitu; proses supervisi klinis, interaksi antara guru dengan murid, performansi guru dalam mengajar, hubungan guru dengan supervisor, dan analisis data berdasarkan peristiwa aktual di kelas. ${ }^{6}$ Tujuan supervisi klinis dalam rangka membantu memodifikasi pola-pola pembelajaran agar mencapai keefektifan. Ada dua sasaran supervisi klinis. Pertama, untuk membangun motivasi dan komitmen kerja guru. Kedua, menyediakan pengembangan staf bagi guru. ${ }^{7}$

Supervisi klinis pada umumnya dilakukan kepala sekolah atau pangewas. Supervisi ini dilakukan untuk meningkatkan kinerja guru khususnya yang dapat dinilai dari aspek administratifnya. Administrasi pendidikan di sini mencakup kegiatan perencanaan, pelaksanaan, pengawasan, dan penilaian. Melalukan supervisi berarti mengadakan pengawasan dan penilaian dari apa yang telah direncanakan dan dilaksanakan dalam kegiatan pendidikan. ${ }^{8}$

Salah satu aspek yang dinilai dalam supervisi klinis ini adalah kinerja guru berbasis kelas. Secara konseptual, penilaian berbasis kelas merupakan penilaian oleh guru dalam rangka proses pembelajaran. Penilaian berbasis kelas adalah proses pengumpulan dan penggunaan informasi dan hasil belajar peserta didik yang dilakukan oleh guru untuk menetapkan tingkat pencapaian dan penguasaan peserta didik terhadap tujuan pendidikan yang telah ditetapkan.? Dalam penilaian berbasis kelas, ada beberapa unsur di dalamnya. Pertama, penilaian prestasi belajar. Kedua, penilaian kinerja. Ketiga, penilaian alternatif. Keempat, penilaian autentik. Kelima, penilaian portofolio. ${ }^{10}$

Supervisi klinis sebenarnya lahir dari profesi medical, yaitu proses pengembangan keterampilan dan pengetahuan peserta pelatihan dalam kegiatan praktik. Hasil laporan riset, kegiatan pendidikan supervisi dilaksanakan untuk perbaikan pembelajaran. Secara umum, supervisi ini atas inisiatif kepala sekolah atau pengawas bukan dari guru. ${ }^{11}$ Penelitian lain di SDIT Bumi Darun Najah Pasuruan juga menunjukkan bahwa implementasi supervisi klinis dalam tiga tahap yaitu tahap perencanaan, tahap pelaksanaan, dan tahap umpan balik telah berjalan dengan baik dan dapat meningkatkan profesionalisme guru. Beberapa upaya

\footnotetext{
${ }^{6}$ M.L Cogan, Clinical Supervision (Boston: Houghton Mifflin, 1973), 54.

${ }^{7}$ Thomas J Sergiovanni; Robert J. Staarratt, Emerging Patterns of Supervision:Human Perspective (New York: Mc Graw Hill Book Company, 2010), 20.

${ }^{8}$ Saiful Arif, "Implementasi Supervisi Klinis Dalam Pendidikan Agama Islam," Jurnal Tadris 3, no. 2 (2008): 166.

9 Sumarna Surapranata; Muhammad Hatta, Penilaian Portofolio (Bandung: Remaja Rosdakarya, 2004), 5.

${ }^{10}$ Zainal Arifin, Evaluasi Pembelajaran (Bandung: Remadja Rosdakarya, 2012), 180-81.

${ }^{11}$ Rugaiyah, "Pengembangan Model Supervisi Klinis Berbasis Informasi Dan Teknologi," Cakrawala Pendidikan XXXV, no. 3 (2016): 422, https://journal.uny.ac.id/index.php/cp/article/viewFile/10429/pdf.
} 
peningkatan dan pengembangan profesional guru telah diusahakan, seperti penguasaan materi, pemilihan metode pembelajaran, dan media yang digunakan. ${ }^{12}$

Penilaian kelas pada intinya berupa kegiatan pendidik berkaitan dengan pengambilan keputusan tentang pencapaian kompetensi atau hasil belajar peserta didik selama mengikuti proses pembelajaran. Dalam hal ini, guru dapat menjadi sasaran penilaian karena yang melakukannya adalah pengawas itu sendiri. Berdasarkan hasil observasi, kinerja guru MI di wilayah Kecamatan Jumo, Kabupaten Temanggung masih rendah.

Dari paparan dan analisis di atas, peneliti akan melakukan supervis klinis pada guru MI di wilayah Kecamatan Jumo, Kabupaten Temanggung. Guru di MI binaan peneliti selaku pengawas wilayah Kemenag Kecamatan Jumo, Kabupaten Temanggung perlu diberikan pembinaan secara khusus dengan menyiapkan waktu yang cukup agar para guru benar - benar memahami masalah penilaian hasil belajar dan dapat mengembangkannya dengan berbagai model penilaian yang ada.

Sehubungan dengan hal di atas penulis perlu melakukan suatu penelitian dalam meningkatkan kinerja guru dengan mengangkat dua rumusan masalah. Pertama, bagaimana peningkatan kinerja guru MI dalam melaksanakan penilaian berbasis kelas melalui supervisi klinis pengawas di MI binaan wilayah Kemenag Kecamatan Jumo, Kabupaten Temanggung Tahun pelajaran 2018-2019? Kedua, bagaimana efektivitas supervisi klinis pengawas sebagai upaya peningkatan kinerja guru MI dalam melaksanakan penilaian berbasis kelas di MI binaan wilayah Kemenag Kecamatan Jumo, Kabupaten Temanggung Tahun pelajaran 2018-2019?

Tujuan utama penelitian ini ada dua. Pertama, peningkatan kinerja guru MI dalam melaksanakan penilaian berbasis kelas melalui supervisi klinis pengawas di MI binaan wilayah Kemenag Kecamatan Jumo, Kabupaten Temanggung Tahun pelajaran 2018-2019. Kedua, mengetahui efektivitas supervisi klinis pengawas meningkatkan kinerja guru MI dalam melaksanakan penilaian berbasis kelas di MI Binaan Wilayah Kemenag Kec. Jumo Kab. Temanggung Tahun pelajaran 2018-2019.

\section{B. Metode}

Metode penelitian ini menggunakan metode Penelitian Tindakan Kepengawasan (PTKp). Dalam pelaksanaan tindakan, rancangan dilakukan dalam 3 siklus yang meliputi perencanaan, tindakan, pengamatan, dan refleksi. Subjek dalam penelitian ini adalah guru MI binaan wilayah Kemenag Kecamatan Jumo, Kabupaten Temanggung yang merupakan sekolah tempat peneliti menjadi pengawas tahun pelajaran 2018-2019.

Alur penelitian tindakan kepengawasan ini dilakukan dengan empat skema. Pertama, perencanaan. Tahapan ini berupa rancangan tindakan yang menjelaskan tentang apa, mengapa, kapan, di mana, oleh siapa, dan bagaimana tindakan tersebut dilakukan. Pada PTKp di mana peneliti dan guru adalah orang yang berbeda, dalam tahap menyusun rancangan harus ada kesepakatan antara keduanya. Rancangan harus dilakukan bersama

12 Yulia Jayanti Tanama; Achmad Supriyanto; Burhanuddin, "Implementasi Supervisi Klinis Dalam Meningkatkan Profesionalisme Guru," Jurnal Pendidikan: Teori, Penelitian, Dan Pengembangan 1, no. 11 (2016): 2231. 
antara guru yang melakukan tindakan dengan peneliti yang mengamati proses jalannya tindakan. Hal tersebut untuk mengurangi unsur subjektivitas pengamat serta mutu kecermatan pengamatan yang dilakukan. Kedua, tindakan. Pada tahap ini, rancangan tindakan tersebut tentu saja sebelumnya telah dilatih kepada pelaksana tindakan (guru) untuk dapat diterapkan di dalam kelas sesuai dengan skenarionya. Skenario dari tindakan harus dilaksanakan dengan baik dan tampak wajar.

Ketiga, pengamatan atau observasi. Tahap ini sebenarnya berjalan bersamaan dengan saat pelaksanaan. Pengamatan dilakukan pada waktu tindakan sedang berjalan, jadi, keduanya berlangsung dalam waktu yang sama. Pada tahap ini peneliti (atau guru apabila ia bertindak sebagai peneliti) melakukan pengamatan dan mencatat semua hal yang diperlukan dan terjadi selama pelaksanaan tindakan berlangsung. Pengumpulan data ini dilakukan dengan menggunakan format observasi / penilaian yang telah tersusun, termasuk juga pengmatan secara cermat pelaksanaan skenario tindakan dari waktu ke waktu serta dampaknya terhadap proses dan hasil belajar siswa. Keempat, refleksi. Tahapan ini dimaksudkan untuk mengkaji secara menyeluruh tindakan yang telah dilakukan, berdasarkan data yang telah terkumpul, kemudian dilakukan evaluasi guna menyempurnakan tindakan berikutnya. Refleksi dalam PTKp mencakup analisis, sintesis, dan penilaian terhadap hasil pengamatan atas tindakan yang dilakukan. Jika terdapat masalah dari proses refleksi maka dilakukan proses pengkajian ulang melalui siklus berikutnya yang meliputi kegiatan: perencanaan ulang, tindakan ulang, dan pengamatan ulang shingga permasalahan dapat teratasi.

Dalam penelitian tindakan kepengawasan ini variabel yang, diteliti adalah peningkatan kinerja guru MI dalam melaksanakan penilaian berbasis kelas melalui penerapan supervisi klinis pengawas di MI binaan wilayah Kemenag Kecamatan Jumo, Kabupaten Temanggung. Sumber data dalam penelitian ini adalah guru dan pengawasan. Teknik pengumpulan data menggunakan observasi dan angket. Dalam analisis data, teknik yang digunakan adalah teknik analisis kuantitatif yaitu digunakan untuk menghitung besarnya peningkatan kinerja guru MI dalam melaksanakan penilaian berbasis kelas di MI Binaan Wilayah Kemenag Kec. Jumo Kab. Temanggung dengan menggunakan persentase (\%). Sedangkan yang kedua menerapkan teknik analisis data kualitatif, yaitu digunakan untuk memberikan gambaran hasil penelitian secara ; reduksi data, sajian deskriptif, dan penarikan simpulan.

\section{Hasil dan Pembahasan}

\section{Perencanaan Tindakan}

Penelitian tindakan ini menggunakan model pembinaan melalui penerapan supervisi klinis pengawas. Tujuan yang diharapkan pada pembinaan pertama pengawas melalui supervisi klinis ini adalah menjelaskan kepada guru dalam rangka peningkatan kinerja guru MI dalam melaksanakan penilaian berbasis kelas.

Agar dapat tercapai tujuan di atas, peneliti yang bertindak sebagai Pengawas melakukan pembinaan dengan langkah-langkah. Pertama, menyusun instrumen penilaian 
sesuai dengan standar pengelolaan pendidikan (8 standar isi pendidikan). Kedua, menyusun Instrumen monitoring. Ketiga, sosialisasi kepada guru. Ketiga, melaksanakan tindakan kepengawasan melalui supervisi klinis. Keempat, melakukan refleksi pada siklus pertama. Kelima, menyusun strategi pembinaan pada siklus ke dua berdasarkan refleksi siklus pertama. Keenam, melaksanakan pembinaan melalui supervisi klinis pada siklus kedua. Ketujuh, melakukan observasi. Kedelapan, melakukan refleksi pada siklus kedua. Kesembilan, menyusun strategi pembinaan melalui supervisi klinis. Kesepuluh, pengawas pada siklus ketiga berdasar refleksi siklus kedua. Kesebelas, melaksanakan pembinaan melalui supervisi klinis pada siklus ketiga. Keduabelas, melakukan observasi. Ketigabelas, melakukan refleksi pada siklus ketiga. Keempatbelas, menyusun laporan.

\section{Pelaksanaan Tindakan dan Pengamatan}

Pelaksanaan tindakan kepengawasan dalam penelitian dilakukan 3 siklus yang terdiri dari tiga kali pertemuan. Waktu yang digunakan setiap kali pertemuan adalah 2 x 60 menit. Pertemuan pertama dilaksanakan pada tanggal 06 September - 13 September 2018 dan pertemuan kedua pada tanggal 20 - 27 September 2018, pertemuan ketiga 06 - 13 Oktober 2018. Penelitian tindakan kepengawasan dilaksanakan sesuai dengan prosedur rencana pembelajaran dan skenario pembelajaran.

\section{SIKLUS 1}

a) Tahap Perencanaan

Pada tahap ini peneliti mempersiapkan perangkat pembinaan berupa perencanaan pembelajaran, pelaksanaan pembelajaran yang sudah distandarisasi dan alat-alat pengajaran lain yang mendukung.

b) Tahap Kegiatan dan Pelaksanaan

Pelaksanaan kegiatan pembinaan untuk siklus I dilaksanakan pada tanggal 06 September - 13 September 2018 di MI Binaan Wilayah Kemenag Kecamatan Jumo, Kabupaten Temanggung tahun pelajaran 2018-2019 dengan jumlah guru 17 orang. Dalam hal ini peneliti bertindak sebagai pengawas. Adapun proses pembinaan mengacu pada rencana pembinaan melalui supervisi klinis yang telah dipersiapkan, dan dilaksanakan pada saat proses belajar mengajar berlangsung.

Pengamatan (observasi) dilaksanakan bersamaan dengan pelaksaaan belajar mengajar. Pada akhir pembinaan diberi tes penilaian I dengan tujuan untuk mengetahui peningkatan kinerja guru MI dalam melaksanakan penilaian berbasis kelas yang telah dilakukan. Adapun data hasil penelitian pada siklus I. adalah seperti pada tabel berikut : 
Tabel 1 :

Distribusi Nilai Peningkatan Kinerja guru MI dalam Melaksanakan Penilaian Berbasis Kelas Melalui Supervisi Klinis Pada Siklus I

\begin{tabular}{|c|c|c|c|c|}
\hline \multirow{2}{*}{ No } & \multirow{2}{*}{ Nama } & \multirow{2}{*}{ Skor } & \multicolumn{2}{|c|}{ Keterangan } \\
\hline & & & Tuntas & Tidak Tuntas \\
\hline 1 & Maskhun S.PdI. & 60 & & $\sqrt{ }$ \\
\hline 2 & Siti Asiyah S.PdI. & 60 & & $\sqrt{ }$ \\
\hline 3 & Genduk Sriningsih S.PdI. & 75 & $\sqrt{ }$ & \\
\hline 4 & Partutik S.PdI. & 75 & $\sqrt{ }$ & \\
\hline 5 & Kurnianingsih. S.Pd & 75 & $\sqrt{ }$ & \\
\hline 6 & Riyanto & 55 & & $\sqrt{ }$ \\
\hline 7 & Ruwanto & 80 & $\sqrt{ }$ & \\
\hline 8 & Nita Saraswati,S.Pd.I & 60 & & $\sqrt{ }$ \\
\hline 9 & Fathurrohman,S.Pd.I & 45 & & $\sqrt{ }$ \\
\hline 10 & Masngudi,S.Pd.I & 75 & $\sqrt{ }$ & \\
\hline 11 & Eni Unaroh,S.Pd.I & 60 & & $\sqrt{ }$ \\
\hline 12 & Rochman & 60 & & $\sqrt{ }$ \\
\hline 13 & Triyono & 60 & & $\sqrt{ }$ \\
\hline 14 & Sugiyati & 75 & $\sqrt{ }$ & \\
\hline 15 & Supiyati, S. Pd.I & 60 & & $\sqrt{ }$ \\
\hline 16 & Arif Maksum, S. Pd.I & 60 & & $\sqrt{ }$ \\
\hline 17 & Ahmadi, S. Pd.I & 60 & & $\sqrt{ }$ \\
\hline \multicolumn{2}{|c|}{ Jumlah Total } & 1095 & & \\
\hline \multicolumn{2}{|c|}{ Skor Maksimum Individu } & 100 & & \\
\hline \multicolumn{2}{|c|}{ Skor Maksimum Kelas } & 1700 & & \\
\hline
\end{tabular}

Keterangan :

Jumlah Guru yang tuntas : : 6 Orang

Jumlah Guru yang belum tuntas : 11 Orang

Sekolah : belum tuntas.

Dari tabel di atas dapat dijelaskan bahwa dengan pembinaan melalui penerapan supervisi klinis pengawas diperoleh nilai rata-rata nilai adalah $64,41 \%$ atau ada 6 orang dari 17 guru sudah tuntas. Hasil tersebut menunjukkan bahwa pada siklus pertama secara keseluruhan belum tuntas, karena guru yang memperoleh nilai $\geq 75$ hanya sebesar 35,29\% lebih kecil dari persentase ketuntasan yang dikehendaki yaitu sebesar $85 \%$. Hal ini disebabkan karena guru masih merasa baru dan belum mengerti apa yang dimaksudkan dan digunakan pengawas dengan menerapkan pembinaan melalui supervisi klinis.

c) Refleksi

Dalam pelaksanaan kegiatan pembinaan diperoleh informasi dari hasil pengamatan sebagai berikut:

(1) Pengawas kurang baik dalam memotivasi guru dan dalam menyampaikan tujuan pembinaan 
(2) Pengawas kurang baik dalam pengelolaan waktu

(3) Guru kurang begitu antusias selama pembinaan berlangsung.

d) Revisi Rancangan

Pelaksanaan kegiatan pembinaan pada siklus I ini masih terdapat kekurangan, sehingga perlu adanya revisi untuk dilakukan pada siklus berikutnya.

(1) Pengawas perlu lebih terampil dalam memotivasi guru dan lebih jelas dalam menyampaikan tujuan pembinaan. Di mana guru diajak untuk terlibat langsung dalam setiap kegiatan yang akan dilakukan.

(2) Pengawas perlu mendistribusikan waktu secara baik dengan menambahkan informasi-informasi yang dirasa perlu dan memberi catatan

(3) Pengawas harus lebih terampil dan bersemangat dalam memotivasi guru sehingga guru bisa lebih antusias.

\section{SIKLUS II}

a) Tahap perencanaan

Pada tahap ini peneliti mempersiapkan perangkat pembinaan yang terdiri dari rencana pembinaan 2, soal tes formatif II dan alat-alat pembinaan lain yang mendukung.

b) Tahap kegiatan dan pelaksanaan

Pelaksanaan kegiatan pembinaan untuk siklus II dilaksanakan pada tanggal 20 27 September 2018 di MI Binaan Wilayah Kemenag Kec. Jumo Kab. Temanggung Tahun pelajaran 2018-2019. Dalam hal ini peneliti bertindak sebagai pengawas. Adapun proses pembinaan mengacu pada rencana pembinaan dengan memperhatikan revisi pada siklus I, sehingga kesalahan atau kekurangan pada siklus I tidak terulang lagi pada siklus II. Penelitian tindakan kepengawasan ini dilaksanakan sesuai dengan prosedur rencana pembinaan dan pelaksanaan pembinaan dilaksanakan pada saat proses belajar mengajar berlangsung. Pada akhir proses pembinaan guru diberi tes formatif II dengan tujuan untuk mengetahui tingkat keberhasilan dalam melakukan pembinaan. Instrumen yang digunakan adalah tes formatif II. Adapun data hasil penelitian pada siklus II adalah sebagai berikut.

Tabel 2 :

Distribusi Nilai Peningkatan Kinerja guru MI dalam Melaksanakan Penilaian Berbasis Kelas Melalui Supervisi Klinis Pada Siklus II

\begin{tabular}{|c|l|c|c|c|}
\hline \multirow{2}{*}{ No } & \multicolumn{1}{|c|}{ Nama } & \multirow{2}{*}{ Skor } & \multicolumn{2}{c|}{ Keterangan } \\
\cline { 4 - 5 } & & & Tuntas & Tidak Tuntas \\
\hline 1 & Maskhun S.PdI. & 80 & $\sqrt{ }$ & \\
\hline 2 & Siti Asiyah S.PdI. & 80 & $\sqrt{ }$ & \\
\hline 3 & Genduk Sriningsih S.PdI. & 85 & $\sqrt{ }$ & \\
\hline 4 & Partutik S.PdI. & 75 & $\sqrt{ }$ & \\
\hline 5 & Kurnianingsih. S.Pd & 75 & $\sqrt{ }$ & \\
\hline 6 & Riyanto & 65 & & $\sqrt{ }$ \\
\hline 7 & Ruwanto & 80 & $\sqrt{ }$ & \\
\hline
\end{tabular}




\begin{tabular}{|c|l|c|c|c|}
\hline 8 & Nita Saraswati,S.Pd.I & 70 & $\sqrt{ }$ & \\
\hline 9 & Fathurrohman,S.Pd.I & 75 & $\sqrt{ }$ & \\
\hline 10 & Masngudi,S.Pd.I & 75 & $\sqrt{ }$ & \\
\hline 11 & Eni Unaroh,S.Pd.I & 75 & $\sqrt{ }$ & \\
\hline 12 & Rochman & 80 & $\sqrt{ }$ & \\
\hline 13 & Triyono & 70 & & $\sqrt{ }$ \\
\hline 14 & Sugiyati & 75 & $\sqrt{ }$ & \\
\hline 15 & Supiyati, S. Pd.I & 80 & $\sqrt{ }$ & \\
\hline 16 & Arif Maksum, S. Pd.I & 80 & $\sqrt{ }$ & \\
\hline 17 & Ahmadi, S. Pd.I & 75 & $\sqrt{ }$ & \\
\hline \multicolumn{2}{|l|}{ Jumlah Total } & 1295 & & \\
\hline \multicolumn{2}{|l}{ Skor Maksimum Individu } & 100 & & \\
\hline
\end{tabular}

\section{Keterangan :}

Jumlah Guru yang tuntas $\quad$ : 14 Orang

Jumlah Guru yang belum tuntas : 3 Orang

Sekolah : belum tuntas.

Dari tabel di atas diperoleh nilai rata-rata yang diperoleh guru adalah 76,17 \% dan peningkatan kinerja guru MI dalam melaksanakan penilaian berbasis kelas atau dari 17 orang guru baru 14 orang yang sudah tuntas ( $82,35 \%)$. Hasil ini menunjukkan bahwa pada siklus II ini hasil pembinaan melalui supervisi klinis telah mengalami peningkatan lebih baik dari siklus I. Adanya peningkatan kinerja guru ini karena pengawas telah menginformasikan bahwa setiap akhir pembinaan akan diadakan penilaian sehingga pada pertemuan berikutnya guru lebih termotivasi untuk meningkatkan kinerjanya. Selain itu para guru juga sudah mulai mengerti apa yang dimaksudkan dan diinginkan oleh pengawas dalam melakukan pembinaan dengan penerapan supervisi klinis.

c) Refleksi

Dalam pelaksanaan pembinaan diperoleh informasi dari hasil pengamatan sebagai berikut:

1) Memotivasi Pengawas

2) Membimbing guru dalam menyusun perencanaan dan pelaksanaan program sekolah, merumuskan kesimpulan/menemukan konsep

3) Pengelolaan waktu

d) Revisi Pelaksanaaan

Pelaksanaan pembinaan pada siklus II ini masih terdapat kekurangankekurangan. Maka perlu adanya revisi untuk dilaksanakan pada siklus III antara lain:

(1) Pengawas dalam memberikan pembinaan kepada guru hendaknya dapat membuat para guru termotivasi dalam membuat program dan rencana pembelajaran. 
$62 \mid$ Peningkatan Kinerja Guru MI ....

(2) Pengawas harus lebih dekat dengan guru sehingga tidak ada perasaan takut/malu dalam diri guru terutama dalam bertanya tentang masalah yang dihadapi oleh sekolah.

(3) Pengawas harus lebih sabar dalam melakukan pembinan kepada guru terutama dalam merumuskan kesimpulan / menemukan konsep.

(4) Pengawas harus mendistribusikan waktu secara baik sehingga kegiatan pembinaan dapat berjalan efektif sesuai dengan yang diharapkan.

(5) Pengawas sebaiknya menambah lebih banyak contoh contoh model penilaian hasil pembelajaran dengan format format yang sudah distandardisasi oleh Departemen Pendidikan Nasional,dalam hal ini Lembaga Penjaminan Mutu Pendidikan ( LPMP ) baik di Tingkat Provinsi maupun tingkat Pusat.

\section{SIKLUS III}

a) Tahap Perencanaan

Pada tahap ini peneliti mempersiapkan perangkat pembinaan yang berkaitan dengan peningkatan kinerja guru MI dalam meningkatkan kinerjanya 3, soal tes formatif 3 dan alat-alat pembinaan lainnya yang mendukung.

b) Tahap kegiatan dan pengamatan

Pelaksanaan kegiatan pembinaan untuk siklus III dilaksanakan pada tanggal 06 - 13 Oktober 2018 di MI Binaan Wilayah Kemenag Kec. Jumo Kab. Temanggung Tahun pelajaran 2018-2019 dengan jumlah 17 orang guru. Dalam hal ini peneliti bertindak sebagai Pengawas. Adapun proses pembinaan mengacu pada rencana pembinaan dengan memperhatikan revisi pada siklus II, sehingga kesalahan atau kekurangan pada siklus II tidak terulang lagi pada siklus III. Pengamatan (observasi) dilaksanakan bersamaan dengan proses belajar mengajar di sekolah.

Pada akhir proses pembinaan diberi tes formatif III dengan tujuan untuk mengetahui tingkat keberhasilan guru meningkatkan kinerjanya dalam pembelajaran di kelas yang telah dilakukan. Instrumen yang digunakan adalah tes formatif III. Adapun data hasil penelitian pada siklus III adalah sebagai berikut :

Tabel 3 :

Distribusi Nilai Peningkatan Kinerja guru MI dalam Melaksanakan Penilaian Berbasis Kelas Melalui Supervisi Klinis Pada Siklus III

\begin{tabular}{|c|l|c|c|c|}
\hline \multirow{2}{*}{ No } & \multicolumn{2}{|c|}{ Nama } & \multirow{2}{*}{ Skor } & \multicolumn{2}{|c|}{ Keterangan } \\
\cline { 3 - 5 } & & & Tuntas & Tidak Tuntas \\
\hline 1 & Maskhun S.PdI. & 90 & $\sqrt{ }$ & \\
\hline 2 & Siti Asiyah S.PdI. & 90 & $\sqrt{ }$ & \\
\hline 3 & Genduk Sriningsih S.PdI. & 95 & $\sqrt{ }$ & \\
\hline 4 & Partutik S.PdI. & 85 & $\sqrt{ }$ & \\
\hline 5 & Kurnianingsih. S.Pd & 85 & $\sqrt{ }$ & \\
\hline 6 & Riyanto & 85 & $\sqrt{ }$ & \\
\hline
\end{tabular}




\begin{tabular}{|c|l|c|c|c|}
\hline 7 & Ruwanto & 90 & $\sqrt{ }$ & \\
\hline 8 & Nita Saraswati,S.Pd.I & 80 & $\sqrt{ }$ & \\
\hline 9 & Fathurrohman,S.Pd.I & 85 & $\sqrt{ }$ & \\
\hline 10 & Masngudi,S.Pd.I & 85 & $\sqrt{ }$ & \\
\hline 11 & Eni Unaroh,S.Pd.I & 85 & $\sqrt{ }$ & \\
\hline 12 & Rochman & 80 & $\sqrt{ }$ & \\
\hline 13 & Triyono & 90 & $\sqrt{ }$ & \\
\hline 14 & Sugiyati & 85 & $\sqrt{ }$ & \\
\hline 15 & Supiyati, S. Pd.I & 90 & $\sqrt{ }$ & \\
\hline 16 & Arif Maksum, S. Pd.I & 90 & $\sqrt{ }$ & \\
\hline 17 & Ahmadi, S. Pd.I & 85 & $\sqrt{ }$ & \\
\hline Jumlah Total & 1475 & & \\
\hline Skor Maksimum Individu & 100 & & \\
\hline Skor Maksimum Kelas & 1700 & & \\
\hline
\end{tabular}

\section{Keterangan :}

Jumlah Guru yang tuntas $\quad: 17$ Orang

Jumlah Guru yang belum tuntas : - Orang

Sekolah

: Sudah tuntas.

Dari tabel di atas diperoleh nilai rata-rata tes formatif sebesar 86,76\% dan dari 17 orang guru semuanya yang telah mencapai ketuntasan meningkatkan kinerjanya dalam melaksanakan penilaian berbasis kelas. Maka secara kelompok ketuntasan telah mencapai $100 \%$ ( termasuk kategori tuntas ). Hasil pada siklus III ini mengalami peningkatan lebih baik dari siklus II. Adanya peningkatan hasil pembinaan pada siklus III ini dipengaruhi oleh adanya peningkatan kemampuan pengawas dalam menerapkan pembinaan melalui supervisi klinis sehingga guru menjadi lebih memahami tugasnya masing masing dan dapat meningkatkan kinerjanya dalam melaksanakan penilaian berbasis kelas. Di samping itu ketuntasan ini juga dipengaruhi oleh kerja sama dari pengawas, dan guru dalam merencanakan dan melaksanakan pembelajaran.

c) Refleksi

Pada tahap ini dikaji apa yang telah terlaksana dengan baik maupun yang masih kurang baik dalam proses pembinaan melalui penerapan supervisi klinis. Dari data-data yang telah diperoleh dapat duraikan sebagai berikut :

(1) Selama proses pembinaan pengawas telah melaksanakan semua pembinaan dengan baik. Meskipun ada beberapa aspek yang belum sempurna, tetapi persentase pelaksanaannya untuk masing-masing aspek cukup besar.

(2) Berdasarkan data hasil pengamatan diketahui bahwa guru aktif selama proses pembinaan berlangsung.

(3) Kekurangan pada siklus-siklus sebelumnya sudah mengalami perbaikan dan peningkatan sehingga menjadi lebih baik.

(4) Hasil pembinaan guru oleh pengawas melalui penerapan supervisi klinis pada siklus III mencapai ketuntasan.

d) Revisi Pelaksanaan 
64 Peningkatan Kinerja Guru MI ....

Pada siklus III pengawas telah melaksanakan pembinaan dengan baik dan dilihat dari peningkatan kinerja guru pelaksanaan pembinaan sudah berjalan dengan baik. Maka tidak diperlukan revisi terlalu banyak, tetapi yang perlu diperhatikan untuk tindakan selanjutnya adalah memaksimalkan dan mempertahankan apa yang telah ada dengan tujuan agar pada pelaksanaan pembinaan selanjutnya baik melalui penerapan supervisi klinis dapat meningkatkan kinerja guru sehingga tujuan pembinaan sebagai upaya meningkatkan mutu pendidikan secara umum dapat tercapai.

\section{Analisis Hasil Kegiatan}

Setelah dilakukan tindakan kepengawasan pada siklus 1, siklus 2 dan siklus 3 menunjukkan hasil sebagai berikut :

Tabel 4 :

Analisis Hasil Tes Tentang Pembinaan Pengawas Melalui Supervisi Klinis Meningkatkan Kinerja guru MI dalam Melaksanakan Penilaian Berbasis Kelas.

\begin{tabular}{|c|l|c|c|c|}
\hline No & \multicolumn{1}{|c|}{ Nama } & Siklus 1 & Siklus 2 & Siklus 3 \\
\hline 1 & Maskhun, S.PdI. & 60 & 80 & 90 \\
\hline 2 & Siti Asiyah S.PdI. & 60 & 80 & 90 \\
\hline 3 & Genduk Sriningsih S.PdI. & 75 & 85 & 95 \\
\hline 4 & Partutik S.PdI. & 75 & 75 & 85 \\
\hline 5 & Kurnianingsih. S.Pd & 75 & 75 & 85 \\
\hline 6 & Riyanto & 55 & 65 & 85 \\
\hline 7 & Ruwanto & 80 & 80 & 90 \\
\hline 8 & Nita Saraswati,S.Pd.I & 60 & 70 & 80 \\
\hline 9 & Fathurrohman,S.Pd.I & 45 & 75 & 85 \\
\hline 10 & Masngudi,S.Pd.I & 75 & 75 & 85 \\
\hline 11 & Eni Unaroh,S.Pd.I & 60 & 75 & 85 \\
\hline 12 & Rochman & 60 & 80 & 80 \\
\hline 13 & Triyono & 60 & 70 & 90 \\
\hline 14 & Sugiyati & 75 & 75 & 85 \\
\hline 15 & Supiyati, S. Pd.I & 60 & 80 & 90 \\
\hline 16 & Arif Maksum, S. Pd.I & 60 & 80 & 90 \\
\hline 17 & Ahmadi, S. Pd.I & 60 & 75 & 85 \\
\hline & Jumlah Total & 1095 & 1295 & 1475 \\
\hline & Skor Maksimum Individu & 100 & 100 & 1700 \\
\hline & Skor Maksimum Kelas & & 1700 & \\
\hline
\end{tabular}

\section{Analisis Data Deskriptif Kuantitatif}

1. Pencapaian peningkatan kinerja guru sebelum diberi tindakan $=\underline{1095} \times 100 \%=64,41 \%$ 
1700

2. Peningkatan kinerja guru setelah diberi tindakan melalui supervisi klinis $=\underline{1295} \times 100 \%=76,17 \%$

1700

2. Peningkatan kinerja guru setelah diberi tindakan melalui supervisi klinis $=\underline{1475} \times 100 \%=86,76 \%$

1700

Dari hasil analisis tersebut dapat disimpulkan ke dalam tiga hal. Pertama, terjadi peningkatan kinerja guru setelah diberi pembinaan melalui supervisi klinis yaitu peningkatan kinerja guru; 64,41 \% menjadi 76,17 \% ada kenaikan sebesar $=11,76 \%$. Kedua, dari sebelum pembinaan ( siklus 1 ) dan setelah pembinaan oleh pengawas sampai dengan ( siklus 2) 64,41 \% menjadi 76,17 \%, dan siklus ke 3 juga mengalami kenaikan menjadi ; $86,76 \%-76,17 \%=10,59 \%$. Ketiga, rata - rata peningkatan kinerja guru MI dalam melaksanakan penilaian berbasis kelas 35,29\% naik menjadi $100 \%$.

Berdasarkan pelaksanaan pembinaan yang telah dilakukan pengawas kepada guru melalui supervisi klinis, maka hasil observasi nilai, dapat disimpulkan ke dalam beberapa hal. Pertama, pertemuan pertama kegiatan pembinaan belum berhasil karena dalam pembinaan pengawas masih terlihat guru belum begitu antusias karena mereka masih menganggap pembinaan pengawas tersebut merupakan tugas baru yang diembannya. Kedua, pembinaan yang dilakukan melalui supervisi klinis, dalam hal peningkatan kinerja guru MI dalam melaksanakan penilaian berbasis kelas belum tampak, sehingga hasil yang dicapai tidak tuntas. Ketiga, karena proses pembinaan melalui supervisi klinis baru mereka laksanakan sehingga guru merasa kaku dalam menerapkannya. Keempat, setelah dijelaskan, mereka bisa mengerti dan buktinya pada pertemuan kedua proses pembinaan pengawas berjalan baik, semua guru aktif dan lebih-lebih setelah ada rubrik penilaian proses, semua guru antusias untuk mengikutinya dan telah mencapai ketuntasan.

\section{Pembahasan Hasil Penelitian}

Melalui hasil penelitian ini menunjukkan bahwa pembinaan pengawas melalui supervisi klinis memiliki dampak positif dalam meningkatkan kinerja guru, hal ini dapat dilihat dari semakin mantapnya pemahaman guru terhadap pembinaan yang disampaikan pengawas ( kinerja guru meningkat dari siklus I, II, dan III ) yaitu masing-masing 64,41\% ; 76,17 \% ; 86,76\% secara kelompok dikatakan tuntas/meningkat karena sudah mencapai ketuntasan. Selanjutnya pada aspek kemampuan pengawas meningkatkan kinerja guru MI dalam melaksanakan penilaian berbasis kelas, berdasarkan analisis data, diperoleh aktivitas guru dalam meningkatkan kinerjanya dalam melaksanakan penilaian berbasis kelas setiap siklus mengalami peningkatan. Hal ini berdampak positif terhadap capaian mutu sekolah yaitu dapat ditunjukkan dengan meningkatnya nilai rata-rata guru pada setiap siklus yang terus mengalami peningkatan.

Pada aspek aktivitas pengawas dan guru dalam pembinaan melalui supervisi klinis, berdasarkan analisis data, diperoleh aktivitas pengawas dan guru yang paling dominan dalam 
kegiatan pembinaan adalah bekerja dengan menggunakan alat/media, mendengarkan/ memperhatikan penjelasan Pengawas, dan diskusi antar antar guru dan pengawas. Jadi dapat dikatakan bahwa aktivitas guru dapat dikategorikan aktif. Sedangkan untuk aktivitas pengawas selama pembinaan telah melaksanakan langkah-langkah metode pembinaan melalui supervisi klinis dengan baik. Hal ini terlihat dari aktivitas guru yang muncul di antaranya aktivitas membuat dan merencanakan program pembelajaran, melaksanakan, memberi umpan balik/evaluasi/tanya jawab di mana prosentase untuk aktivitas di atas cukup besar.

Berdasarkan hasil penelitian di atas, peningkatan kinerja guru MI dalam melaksanakan penilaian berbasi kelas, hasilnya cukup baik. Hal itu tampak pada pertemuan dari 17 orang guru yang ada pada saat penelitian ini dilakukan nilai rata rata mencapai ; $64,41 \%$ meningkat menjadi 76,17\% pada siklus 2 siklus ke 3 meningkata menjadi 86,76 $\%$.

Dari analisis data di atas bahwa pembinaan pengawas melalui supervisi klinis efektif diterapkan dalam upaya meningkatkan kinerja guru MI dalam melaksanakan penilaian berbasis kelas, yang berarti proses pembinaan pengawas lebih berhasil dan dapat meningkatkan kinerja guru khususnya di MI Binaan Wilayah Kemenag Kec. Jumo Kab. Temanggung Tahun pelajaran 2018-2019, oleh karena itu diharapkan kepada para pengawas dapat melaksanakan pembinaan melalui supervisi klinis secara berkelanjutan.

Berdasarkan Permen No 12 Tahun 2007 tentang kompetensi pengawas, dapat meningkatkan kinerja guru, serta dapat mengorganisasikan sekolah kearah perubahan yang diinginkan telah mencapai $85 \%$ ketercapaiannya, maka kinerja guru MI dalam melaksanakan penilaian berbasis kelas dengan menerapkan supervisi klinis tersebut dikatakan efektif. Dengan demikian maka hipotesis yang diajukan di atas dapat diterima.

\section{E. Kesimpulan}

Berdasarkan analisis hasil penelitian dan diskusi dapat disimpulkan ke dalam beberapa hal. Pertama, pembinaan pengawas dalam upaya meningkatkan kinerja guru MI dalam melaksanakan penilaian berbasis kelas melalui penerapan supervisi klinis menunjukan peningkatan pada tiap-tiap putaran (siklus). Kedua, aktivitas dalam kegiatan pembinaan pengawas menunjukan bahwa seluruh guru dapat meningkatkan kinerjanya dengan baik dalam setiap aspek. Ketiga, peningkatan kinerja guru oleh pengawas melalui supervisi klinis ini menunjukan peningkatan pada tiap-tiap putarannya. Keempat, aktivitas guru menunjukan bahwa kegiatan pembinaan melalui penerapan supervisi klinis bermanfaat dan dapat membantu guru untuk lebih muda memahami konsep peran dan fungsi guru sehingga peningkatan kinerja guru MI dalam mengajar di sekolah dapat berjalan baik, dan dengan demikian peningkatan kinerja guru dapat ditingkatkan.

Penelitian perlu dilanjutkan dengan serangkaian penelitian yang mengembangkan alat ukur keberhasilan yang lebih reliabel agar dapat menggambarkan peningkatan kinerja guru MI dalam mengajar di kelas dengan baik sehingga mutu pendidikan dapat ditingkatkan. Pembinaan pengawas melalui penerapan supervisi klinis diperlukan perhatian penuh dan disiplin yang tinggi pada setiap langkah pembinaan,dan perencanaan yang matang misalnya 
dalam pengalokasian waktu dan pemilihan konsep yang sesuai. Kepada guru diharapkan selalu mengikuti perkembangan jaman, terutama dengan membaca hasil karya para akhli sehingga tidak ketinggalan dengan daerah lain, dalam meningkatkan mutu pendidikan, sebagai tanggung jawab bersama memajukan pendidikan.

\section{Daftar Pustaka}

Arif, Saiful. "Implementasi Supervisi Klinis Dalam Pendidikan Agama Islam.” Jurnal Tadris 3 , no. 2 (2008).

Arifin, Zainal. Evaluasi Pembelajaran. Bandung: Remadja Rosdakarya, 2012.

Burhanuddin, Yulia Jayanti Tanama; Achmad Supriyanto; "Implementasi Supervisi Klinis Dalam Meningkatkan Profesionalisme Guru." Jurnal Pendidikan: Teori, Penelitian, Dan Pengembangan 1, no. 11 (2016): 2231-2235.

Cogan, M.L. Clinical Supervision. Boston: Houghton Mifflin, 1973.

Hatta, Sumarna Surapranata; Muhammad. Penilaian Portofolio. Bandung: Remaja Rosdakarya, 2004.

Ibda, Hamidulloh. "Peningkatan Kompetensi Profesional Guru SD/MI Melalui Menulis Di Media." Tarbawi: Jurnal Pendidikan Islam 14, no. 1 (2017): 45-62. https://ejournal.unisnu.ac.id/JPIT/article/view/610.

Ibda, Hamidulloh; Wijayanti, Dian Marta. Siapkah Saya Menjadi Guru SD Revolusioner? Depok: Kalam Nusantara, 2014.

Lailatussaadah. "Upaya Peningkatan Kinerja Guru.” INTELEKTUALITA 3, no. 1 (2015).

Muhardi. "Peningkatan Kinerja Guru Dalam Melaksanakan Pembelajaran Yang Efektif Melalui Supervisi Observasi Kelas Di SMK Negeri 1 Sambelia Tahun Pelajaran 2018/2019." Journal Ilmiah Rinjani_Universitas Gunung Rinjani 7, no. 2 (2019).

Mulyasa, E. Menjadi Guru Profesional, Menciptakan Pembelajaran Kreatif Dan Menyenangkan. Bandung: Remadja Rosdakarya, 2009.

Rugaiyah. "Pengembangan Model Supervisi Klinis Berbasis Informasi Dan Teknologi." Cakrawala Pendidikan XXXV, no. 3 (2016). https://journal.uny.ac.id/index.php/cp/article/viewFile/10429/pdf.

Staarratt, Thomas J Sergiovanni; Robert J. Emerging Patterns of Supervision:Human Perspective. New York: Mc Graw Hill Book Company, 2010. 